\title{
Education Game of Javanese Language for 2nd Grade of Elementary Schools
}

\author{
Irse Surya Bagaskara \\ Unika Soegijapranata \\ J1.Pawiytan Luhur IV, Semarang, Indonesia \\ irsemoticon@gmail.com
}

\begin{abstract}
Local language isoften used to communicate in daily life, but in the case offormal study it is very different. Some kids are more frequently using Indonesian language to communicate with each other, sothe kids don't understand Javanese language lessons at school. Therefore, we hope this game "Si Nau" can be the alternate of learning media, so that kids can more understand about Javanese language lessons at school. This research contains the resultsof how to formulate an interesting game forJavaneselanguage, to formulate a game that include gameplay under delivery method so that kids can understand about Javaneselanguage, and also the impact of game "Si Nau" on children. The research result shows that the most of children become interested in Javaneselanguage lessons at school or in the neighborhood they live, the children are also able to understand the Javaneselanguage lessons at school, and some parents also makes this game "Si Nau" as the alternate of learning media at home.
\end{abstract}

Keywords - Game, Education, Learning Media, Si Nau, Java Language

\section{INTRODUCTION}

Elementary education is an education that intend to educate and make kids love and be proud of their na tion a nd country, to make them creative and able to solve the problem in their $\mathrm{n}$ eighboorhood. Elementary school are required for kids 6-12 years old. Some of the lesson learned in elementary school are, religious educ ation, education of $\mathrm{P}$ ancasila and citizenship, Indonesian, mathematics, science, $\mathrm{s}$ ocial, art and culture, pysical education, local 1 anguage, etc. Local languages al so play important ro le $\mathrm{i} n$ primary school e ducation because $i$ inderectly bui ld kids' characteristics, and introduces the hi story a nd c ultures o $\mathrm{fa}$ particular $\mathrm{r}$ egion, etc. Because $\mathrm{t}$ his 1 ocal language i s of ten used in daily 1 ife, the lesson should be easier to learn.

The co mmon pr oblems $t$ hat a re of ten encountered, kids more often use Indonesian language to comunicate with friend or o ther people. E ven if ki ds us e Javaneselanguage, kids a re $m$ ore of ten use ngokoJavaneselanguage $\mathrm{t}$ han kramaJavaneselanguage that is $\mathrm{m}$ ore pol ite. This i s be cause $t$ here ar e s everal $f$ actors including, school teachers use Indonesian as an $\mathrm{i}$ ntroduction to learning $\mathrm{t}$ he $\mathrm{J}$ ava language, learning $\mathrm{m}$ ethods ar e 1 ess attractive so that kids become less motivated to learn Java 1 anguage, some $f$ amily environment ki ds a re onl y given Indonesian as a 1 anguage of da ily com unication and some parents are using ngoko Java language to communicate with their kids.

As a cas e s tudy $t$ aken in S DN S rondol Wetan 02, S DN S rondol Wetan 03, S DN Srondol Wetan 04, S DN Srondol Wetan 05, children's 2nd grade at elementary school is still di fficult $t$ o learn the 1 esson of $J$ ava language. Problems $f$ aced by $t$ eacher ar e, kids are less able to understand krama Java language, and more frequent use Indonesian or ngoko Java. In fact kids are easier to learn English language than Java 1 anguage. This could be be cause $\mathrm{k}$ ids $\mathrm{r}$ arely $\mathrm{r}$ eceive $\mathrm{t}$ he knowledge of Javaneselanguage at home. So at school, kids found it difficult.

Because of that, we need a media to help kids of el ementary s chool in the proc ess of learning $\mathrm{t}$ he Javaneselanguage. The development of $\mathrm{t}$ echnology $\mathrm{t}$ odaycan be 
helpful i $\mathrm{n} 1$ earning $\mathrm{m}$ edia. $\mathrm{O}$ ne of $\mathrm{t}$ hem through the game, with game we can pack into an insteresting 1 esson. Children's 2 nd grade of el ementarys chool ar e still interested to $\mathrm{pl}$ ay game, so with the game kids do not just play but al so learn the lesson. I $\mathrm{n}$ a ddition,parents can still guide their children.

\section{LITERATURE REVIEW}

\subsection{Javanese Language Education in 2nd Grade of Elementary School}

Javaneselanguage $\mathrm{i}$ s one of $\mathrm{t}$ he 1 ocal languages from I ndonesia w hich is part of Indonesian culture, that still con tinues to be used byt he com munity 1 angauges concerned. Javaneselanguage $s$ hould be preserved so that its existence isn't lost.[5]

\subsection{The Purpose of Java Language Education}

Javaneselanguage educ ation $\mathrm{i} \quad \mathrm{n}$ elementary s chool ha s s everal obj ectives, including [6]:

a. Student $\mathrm{c}$ an a ppreciate and be proud of $t$ he Javaneselanguage as 1 ocal language, so s tudent obl iged to preserve that language.

b. Student c an unde rstand Javaneselanguage i $\mathrm{n} \mathrm{t}$ erm of form language, $m$ eaning a nd func tion of the Javanese language.

c. Student can use t he Javanese language properly.

d. With the ability t o use Javanese language, student are expected to use them $\mathrm{t} o$ impove $\mathrm{s}$ kills, intellectual ability, emotional and social maturity.

e. Students are abl e t o be pos itive i $n$ daily life

\subsection{The Function of Javanese Language}

According to Sabdwara (S upartinah, 2010L24), the function of Javanese language includes:

a. Javanese language is a 1 anguage of culture, be cause o $\mathrm{ft}$ hat Javanese language not only use to comunicate, but al so means $t$ he embodiment of cultural attitudes.

b. Knowing the 1 imits of cour tesy, knowing how to us e it and ha ve a sense of re sponsibility for $t$ he improvement of living together.

c. To achieve $\mathrm{t}$ hat po liteness, the conditions $\mathrm{t}$ hat $\mathrm{m}$ ust be taken as follows:

1) Can be $s$ tressful $f$ eelings of others in the association.

2) Be able to honor fri end a nd foe alike.

3) Can ke ep the s peech, no t ha rsh and don't hurt other people.

\section{RESEARCH METHODOLOGY}

\subsection{Game Development Methods}

This $r$ esearch begins with literature review. The purpose of literature review is to sharpen $\mathrm{t}$ he probl em, $\mathrm{f}$ ind information, problem s olving. After doi ng 1 iterature review, fol lowed b y s urvey of 1 earning method in schools to get interesting learning method. Then proc eed to de sign gameplay and making of the game. After that the game can be tested. And a fter testing is done, we can publish it.

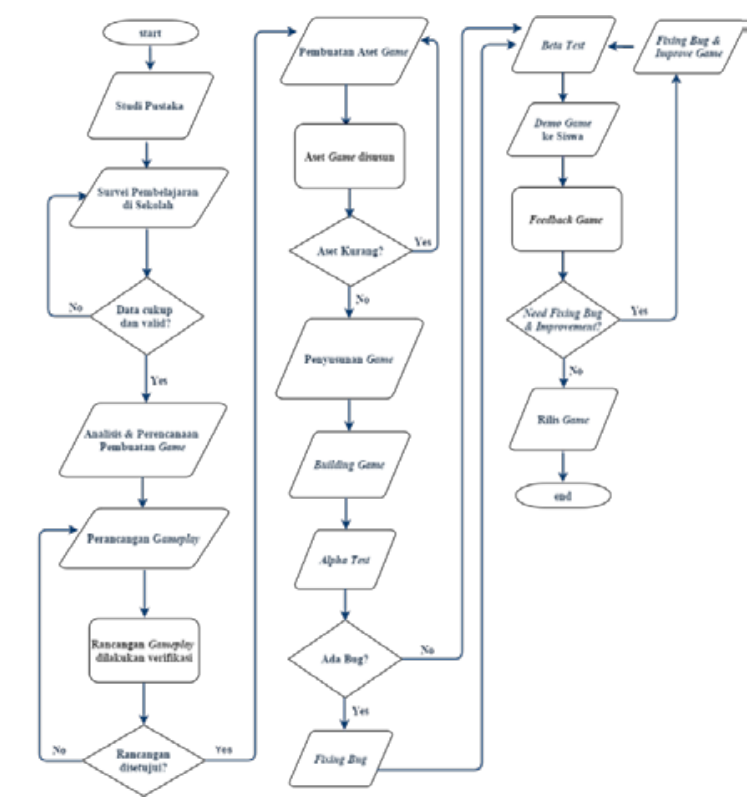

Fig. 1 Flowchart Framework 


\subsection{The Concept of Submission Game}

Later, after $\mathrm{t}$ he $\mathrm{g}$ ame is completed, it will be publicized to parents and his child. Of c ourse,parents are simplyt old that thisJavanese language 1 earning g ame gives less impact on their children. Therefore made the con cept of de livering games to children from $t$ heir pa rents, so that chi ldren can understand some things, both of how to play the game unt il the lesson is delivered. This game not onl y m ake ki ds unde rstand a bout Javanese language, but al so make pa rentchild relationship closer.

\section{RESULTS AND DISCUSSION}

\subsection{The Making of Game}

After formulating the game, both in terms of gameplay and display interface, we started to manufacture the game. In making required some supporting s oftware such as Cons truct 2 game engine and Adobe Photoshop as the graphics proc essing s oftware. We ch ose Construct 2 a s a game eng ine be cause the software $w$ as eas y to operate, light on the results of $t$ he $g$ ame and multi-platform (applications $\mathrm{c}$ an be run $\mathrm{s}$ everal ope rating systems). The selection of Adobe Photoshop as the graphics proc essor for c olor selection and $\mathrm{c}$ olor $\mathrm{m}$ anipulation i $\mathrm{n}$ the $\mathrm{s}$ oftware i $\mathrm{s}$ very diverse. Here to see the results of game:

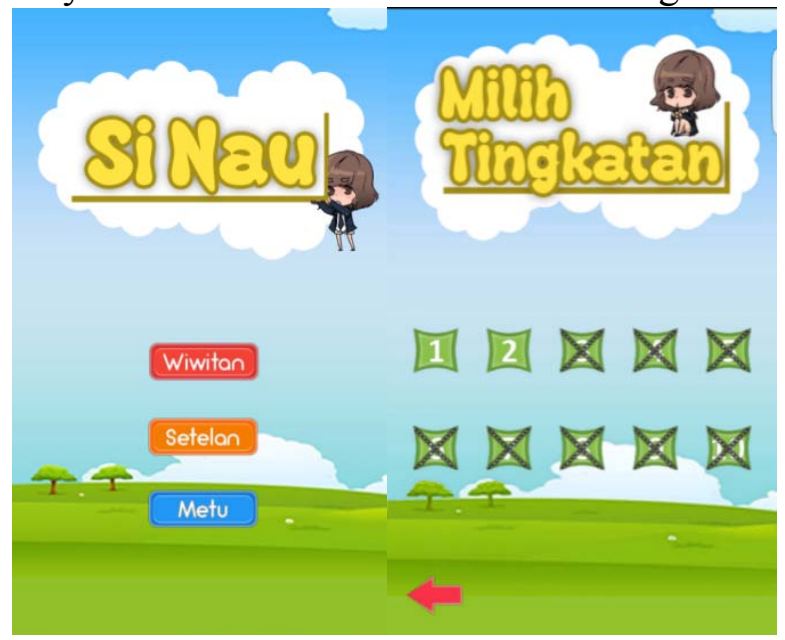

(a)

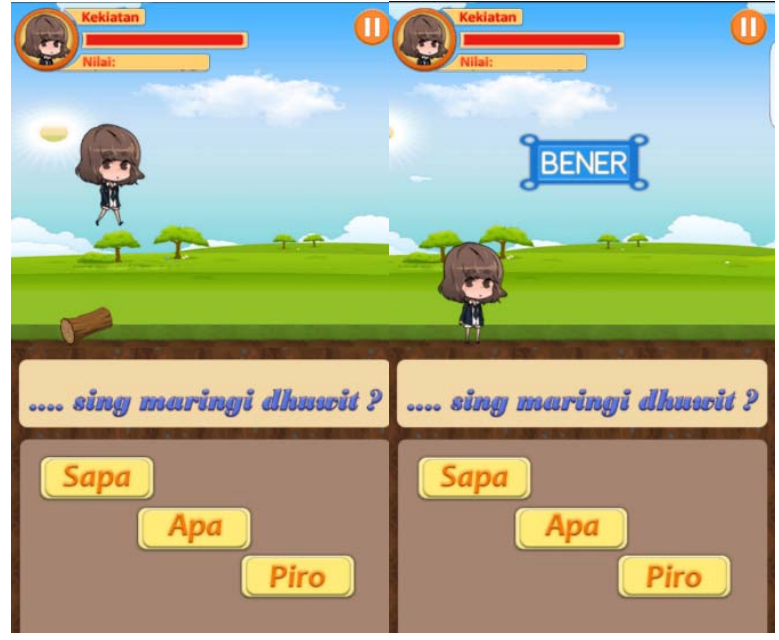

(b)

\subsection{Delivery Method}

The purpos e of $\mathrm{m}$ aking $\mathrm{t}$ his $\mathrm{g}$ ame is $\mathrm{t} o$ make this game as alternative learning media at home. So in that case, the suitable method for de livery $\mathrm{t}$ o ki ds i s to use di scussion method. It means that parent and their kids interact di rectly $\mathrm{i} n$ learning Javanese language while playing this game [14]. When the children at home, parents will teach and educate them [15]. Anyway, pa rent $c$ an not let their kids learn on their own. It just makes them become add icted to the game without having $t$ o unde rstand or $\mathrm{c}$ omprehend the essence of learning in the game.

\subsection{Review Game}

\section{a. Impact of Game}

Having conduc ted trials in children, it is expected after $p$ laying $t$ his $g$ ame that the children's i nterest i n learning the Javanese language is i ncreasing. Here ar e the r esults of a que stionnaire on the i mpact of $t$ his game.

Table 1. Respondents Result

\begin{tabular}{|l|c|c|}
\hline \multicolumn{1}{|c|}{ Review } & $\begin{array}{c}\text { percentage } \\
\text { YES }\end{array}$ & $\begin{array}{c}\text { percentage } \\
\text { NO }\end{array}$ \\
\hline $\begin{array}{l}\text { Child's interest in } \\
\text { learning t he } \\
\text { Javaneselanguage } \\
\text { with this game }\end{array}$ & $87,5 \%$ & $12,5 \%$ \\
\hline Kids m ore & $82,5 \%$ & $17,5 \%$ \\
\hline
\end{tabular}




\begin{tabular}{|l|l|l|}
\hline $\begin{array}{l}\text { understand a bout } \\
\text { Javanese } \\
\text { language t hrough } \\
\text { this game }\end{array}$ & & \\
\hline $\begin{array}{l}\text { Game can help in } \\
\text { learning Javanese } \\
\text { language }\end{array}$ & $87,5 \%$ & $12,5 \%$ \\
\hline $\begin{array}{l}\text { With the g ame } \\
\text { method c an be } \\
\text { useful in learning } \\
\text { the Javanese } \\
\text { language }\end{array}$ & $87,5 \%$ & $12,5 \%$ \\
\hline
\end{tabular}

\section{b. About this Game}

Then the qu estionnaire con tinues on the game itself, which is about the ease of chi ldren in playing this game and understand $t$ he instructions $g$ ame i $n$ this g ame. Here are the results of the questionnaire.

Table 2. Respondents Result

\begin{tabular}{|l|c|c|}
\hline \multicolumn{1}{|c|}{ Review } & $\begin{array}{c}\text { percentage } \\
\text { YES }\end{array}$ & $\begin{array}{c}\text { percentage } \\
\text { NO }\end{array}$ \\
\hline $\begin{array}{l}\text { Ease i n playing } \\
\text { this game }\end{array}$ & $89,7 \%$ & $10,3 \%$ \\
\hline $\begin{array}{l}\text { The i nstruction } \\
\text { can be } \\
\text { understood }\end{array}$ & $84,6 \%$ & $15,4 \%$ \\
\hline
\end{tabular}

\section{CONCLUSIONS}

Game "Si Nau" is a game that is created as a $\mathrm{m}$ eans of 1 earning $\mathrm{m}$ edia about $\mathrm{t}$ he Javanese language to children of $2 \mathrm{nd} g$ rade elementary s chool.This g ame com bines two types of games i.e. trivia and adventure.We hope it $\mathrm{m}$ akes kids i nteresting to play this game. There are 2 characters in this game, a boy and a girl, so anyone can play it.Game "Si N au" is successfully de signed a nd bui lt to be $\mathrm{pl}$ ayed on Android-based ope rating systems and can be downloaded on the Play Store.

This $\mathrm{g}$ ame ha $\mathrm{s}$ be en implementing mentoring a nd di scussion a s a 1 earning delivery methods that make children become active and enthusiastic i $\mathrm{n}$ learning the Javanese language. It al so makes chi ldren become more understanding of $t$ he Javanese language 1 essons and add alternative educational game to be played with parents at home.

With the $g$ ame " Si N au", make t he children understand about Javanese language lessons at $\mathrm{s}$ chool or i $\mathrm{n}$ the ne ighborhood he lives and children to become i nterested i $\mathrm{n}$ learning the Javanese language. This g ame also introduces the child that games could be a learning media. In future we hope that this game can help directly to educate ki ds i n schools

\section{ACKNOWLEDGEMENT}

The authors g ratefully a cknowledgeto Beasiswa Unggulan scholarship and Ministry ofEducation and Culture of Indonesia.

\section{REFERENCES}

[1] Pusat B ahasa Departemen Pendidikan Nasional, Kamus B esar B ahasa Indonesia, Jakarta: Balai P ustaka, 2002.

[2] Republik Indonesia, 2003, U ndang Undang No. $20 \mathrm{~T}$ ahun $2003 \mathrm{P}$ asal 3 tentang Pendidikan, Jakarta.

[3] Adminsidiknas, "Sekolah Dasar", Kementerian Pendidikan da n Kebudayaan Re publik I ndonesia, 26 Maret 2012, [O nline]. Tersedia: http://www.kemdiknas.go.id/kemdikb ud/peserta-didik-sekolah-dasar [Diakses: 24 Agustus 2015].

[4] Soekidjo N atoatmodjo, P endidikan dan Perilaku Kesehan, Jakarta: P T. Rineka Cipta, 2003.

[5] Tim $\mathrm{K}$ urikulum, $\mathrm{K}$ urikulum $\mathrm{M}$ ata Pelajaran Bahasa Jawa Sekolah Dasar dan YogyakartaMadrasah Ibtidaiyah, Daerah Istimewa Y ogyakarta: D inas Pendidikan Provinsi DIY. 2004.

[6] Tim $P$ roseding $M$ ateri $K$ ongres Bahasa J awa Tahun 1991, K ongres Bahasa J awa, Surakarta: K anthil, 1991. 
[7] Sry $\mathrm{S}$ atriya $\mathrm{Tj}$ atur $\mathrm{W}$ isnu Sasangka, Unggah $U$ ngguh Bahasa $J$ awa, Jakarta: Yayasan Paralingua, 2009.

[8] Amrih P rasaja, Setya, E-Learning Bahasa $J$ awa S MAN 1 Sanden, Bantul - Daerah Istimewa Yogyakarta.

[9] Bastomi, Suwaji, Seni da n Budaya Jawa, Semarang: IKIP S emarang Press, 1992.

[10] Mahtarami, Affan, dan W.D Andario, Pengembangan Konten e -Learning Berbasis $G$ ame Komputer $U$ ntuk Materi Ekspresi Reguler, Yogyakarta: SNATI, 2010.

[11] Aeni, W. A, Antara Game, Pendidikan dan HP ( Game M obile Learning Sebagai Wacana Pendidikan), 2009.
[12] Henry, Samuel, Cerdas dengan Game, PT Gramedia Pustaka Utama, 2010.

[13] “Apa Itu GUI?” [Online]. Tersedia di: https://andrasana.wordpress.com/2009 /10/01/apa-itu-gui-graphical-userinterface/. [Diakses: 26-Juni-2016].

[14] Hariyanto, "Macam - Macam Metode Pembelajaran" [ Online]. Tersedia di : http://belajarpsikologi.com/macammacam-metode-pembelajaran/. [Diakses: 29-Juni-2016].

[15] "Konsep P endidikan A nak di Lingkungan Keluarga" [ Online]. Tersedia d i: http://www.matrapendidikan.com/201 5/10/pendidikan-anak-di-lingkungankeluarga.html. [Diakses: 29-Juni2016]. 